\title{
Initial Coin Offering (ICO) in Perspective Law of Sharia Business
}

\author{
Imam Subarkah \\ Universitas Islam Negeri Sunan Kalijaga Yogyakarta - Indonesia \\ e-mail: arkarudjito@gmail.com
}

\begin{abstract}
Tixl (TXL) is a crypto money project that uses Initial Coin Offering (ICO) to fund its development phase. Various problems underlying the existence of Tixl (TXL) and the proposed solutions are closely related to the condition of society in the information technology era. This study aims to determine the various factors underlying the use of ICO as a way to raise funds, examine Tixl (TXL) as a crypto money project and its position in public life which is reviewed in the perspective of the maslaha mursala, and token sales transactionsin ICO organized by Tixl gmmbH in the perspective of Islamic treaty law. This research is a library research using a conceptual approach and qualitative analysis techniques. This paper shows that there are three factors underlying the use of ICOs as a way to raise funds, namely a change in orientation in the business model, tokenization, and characteristics of business activities. As a crypto money project, Tixl (TXL) cannot provide benefits that are comprehensive or kully, even the harm caused is greater than the benefits. Transaction of token sales in ICO held by Tixl (TXL) is a transaction that is damaged because it is contrary to maqūșid al-sharì'ah.
\end{abstract}

Keywords: Initial Coin Offering (ICO), crypto money, mașlaha mursala, maqāṣid alsharı̈a

Tixl (TXL) merupakan salah satu proyek uang kripto yang menggunakan Initial Coin Offering (ICO) untuk mendanai fase pengembangannya. Berbagai permasalahan yang melatarbelakangi eksistensi dari Tixl (TXL) dan solusi yang diajukan berkaitan erat dengan kondisi masyarakat di era teknologi informasi. Penelitian ini bertujuan untuk mengetahui berbagai faktor yang melatarbelakangi penggunaan ICO sebagai sebuah cara pengumpulan dana, menelaah Tixl (TXL) sebagai sebuah proyek uang kripto dan kedudukannya dalam kehidupan masyarakat yang ditinjau dalam perspektif mașlahah mursalah, dan transaksi penjualan token dalam ICO yang diselenggarakan oleh Tixl gGmbH dalam perspektif hukum perjanjian Islam. Penelitian ini merupkan penelitian kepustakaan menggunakan pendekatan konseptual serta teknik analisis kualitatif. Paper ini menunjukkan bahwa terdapat tiga hal yang melatarbelakangi penggunaan ICO sebagai cara pengumpulan dana, yaitu perubahan orientasi dalam model bisnis, adanya tokenisasi, dan karakteristik kegiatan usaha. Sebagai sebuah proyek uang kripto, Tixl (TXL) tidak dapat memberikan kemaslahatan yang bersifat menyeluruh atau kully, bahkan madarat yang ditimbulkannya lebih besar daripada kemaslahatannya. Transaksi penjualan token dalam ICO yang diselenggarakan Tixl (TXL) merupakan transaksi yang bāțil karena bertentangan dengan maqāṣid alsharìah.

Kata Kunci: Initial Coin Offering (ICO), uang kripto, mașlaḥah mursalah, maqāṣid alsharīah 
Imam Subarkah

\section{Introduction}

The development of information technology has changed the pattern of interaction between people. Information and connectivity are two keywords that can describe the modern world today. Information will not be used optimally without connectivity between people and other systems. However, only good and secure connectivity can encourage optimal information exchange. ${ }^{1}$

Blockchain is a new approach to both. Blockchain is growing rapidly and is now used in various fields, especially related to finance and business. Blockchain began to bloom after the emergence of Bitcoin, a peer-to-peer electronic payment system that makes online payments can occur directly from one party to another. ${ }^{2}$

Blockchain is a new approach to both. Blockchain is growing rapidly and is now used in various fields, especially related to finance and business. Blockchain began to bloom after the emergence of Bitcoin, a peer-to-peer electronic payment system that makes online payments can occur directly from one party to another. ${ }^{3}$

Today, the existence of bitcoin (BTC) has inspired many parties to develop various similar projects. There are also those who try to implement a different concept from bitcoin (BTC), as Ethereum did with the concept of smart contract. ${ }^{4}$ In addition, there are also those who seek to develop the concept of a private payment system, such as Monero (XMR).

\footnotetext{
1 Dimaz Ankaa Wijaya; Oscar Darmawan, Blockchain Dari Bitcoin Untuk Dunia (Jasakom, 2017), 19.

2 The idea of blockchain was introduced since 1991 in a study conductedby stuart Haber and W. Scott Stornetta. Hober and Stornetta introduce a practical computational solution for digital document registration, so that they cannot be changed or twisted.Satoshi Nakamoto, 'Bitcoin: A Peer-to-Peer Electronic Cash System', n.d., 1, www.bitcoin.org.

${ }^{3}$ Brian Kelly, The Bitcoin Big Bang (Jakarta: PT Elex Media Komputindo, 2018), 15.

4 Ethereum uses the blockchain by allowing everyone in the network to make financial contracts with other users who are in it. This financial contract is known as a smart contract. The first person to put forward the idea of a smart contract (smart contract) is a professor in the field of law that is Nick Szabo. In his article entitled "The Idea of Smart Contracts", Nick Szabo described a contract clause that could be digitally attached to an asset. In fact, in this article, Nick Szabo not only illustrates the idea of a car alarm system, but also examines how smart contracts can be used for peer-to-peer lending. Because smart contracts are attached to every collateral borrowed, if the borrower breaches the contract, ownership of the asset will easily change back to the lender of the fund.Chris Dannen, Introducing Ethereum and Solidity (New York: Apress, 2017), 2; Kelly, The Bitcoin Big Bang, 184.
} 
Monero (XMR) is a type of crypto money that is fully anonymous or completely anonymous. This trait is derived from the technique he adopted, namely CryptoNote developed by Nicolas van Saberhagen. CryptoNote was developed because of the fact that bitcoin (BTC) does not meet the criteria for anonymous crypto money. Monero (XMR) is a fork of cryptocurrency bytecoin with several improvements, including improvements to the source code, improved coin supply mechanism and accelerated formation of new blocks from 120 to 60 seconds. ${ }^{5}$

There is also another crypto money that seeks to develop the same idea with Monero (XMR), namely Tixl (TXL). Tixl (TXL) is a crypto money that offers transactions instantly and without fees. The slogan used by Tixl is "Preserving the Essential Properties Of Traditional Money: Private, Instant, Zero-fees".6

The slogan describes the problem Tixl wants to solve, namely the absence of crypto money that can provide private, instant and free transaction services at the same time. Tixl uses various advanced technologies that are expected to solve these problems, such as the Directed Acyclic Graph (DAG) data structure used in conjunction with the Stellar Consensus Protocol (SCP), Zero Knowledge Proofs (ZKP), and Quantum Secure Cryptosystems. ${ }^{7}$ However, currently Tixl (TXL) is still in the fundraising phase, which is known as the Initial Coin Offering (ICO).

Initial Coin Offering (ICO) is a fund collection method that has developed in the early development of the crypto asset industry, and is increasingly used in 2017 and 2018. The increasing number of Initial Coin Offering (ICO) events has

\footnotetext{
${ }^{5}$ Fork has a characteristic that is also like a fork, which ends a lot. In a decentralized and democratic blockchain system, users do not always have a unanimous voice about whatever happens in the system. There are several types of forks, forks related to the process of creating blocks and forks related to software development. Fork related to the process of creating blocks is known as branching blocks, while forks related to software development are divided into two, namely soft fork and hard fork. Soft fork is a type of fork that generally does not interfere with protocols, because it still maintains compatibility with older versions of software. While hard forks are a type of software development forks that cause new versions of software to become incompatible with old versions of software, often hard forks can cause the formation of new types of crypto assets. The most popular example is Ethereum, with the emergence of Ethereum Classic which is supported by those who reject the hard forks submitted by the Ethereum community. Darmawan, Blockchain Dari Bitcoin Untuk Dunia, 23-26, 214.

${ }^{6}$ Christian Eichinger etal,, 'Tixl Whitepaper', 2019, i, https://medium.com/tixlcurrency/tixl-tokensale-phase-3-official-start-41a9f0ee504c.

${ }^{7}$ Eichinger etal, i.
} 
Imam Subarkah

also been followed by a variety of fundamental issues, such as misuse, minimal quality, and problems with governance. ${ }^{8}$ This was also confirmed by the Satis Group, through the results of his study which showed that the percentage of Initial Coin Offering (ICO) which was categorized as a scam had reached 78\%, while $4 \%$ of the Initial Coin Offering (ICO) held had failed in the project, 3\% Initial Coin Offers (ICOs) were held that failed to enter the exchange, and only $15 \%$ succeeded. ${ }^{9}$

This negative trend was also justified by Cura Network, one of the organizers of the Initial Coin Offering (ICO) in 2018. Cura Network has stopped holding the Initial Coin Offering (ICO) on May 6, 2019, whereas the Initial Coin Offering (ICO) is scheduled to end on August 26, 2019. Cura Network said that negative trends within the scope of the Initial Coin Offering (ICO), such as fraud related to the Initial Coin Offering (ICO), had created a bad reputation for the Initial Coin Offering (ICO) and placed start-ups that were connected with Initial Coin Offering (ICO) in a difficult position to meet with potential investors. ${ }^{10}$

Then, what about Tixl (TXL) which is currently in the ICO phase? Tixl (TXL) itself has gained a place in contemporary business. Various problems underlying the existence of Tixl (TXL) and proposed solutions are closely related to the condition of society in the information technology era. The Tixl Team's desire to develop private, fast and free crypto money is different from what has been offered by many payment system service providers in the mainstream.

Tixl (TXL) has the potential to gain a place in various countries that have Muslim populations, including in Germany, where the Tixl Team registered Tixl gGmbH as a legal entity. Germany has the largest Muslim population in Europe after the French state. More than 4 million Muslims or about $5 \%$ of the total population, namely 82 million people who live in Germany. Although a minority, Islam is the third largest religion after Protestant and Catholicism. ${ }^{11}$ Tixl (TXL)

\footnotetext{
8 Wulf A. Kaal; Marco Dell'Erba, 'Initial Coin Offerings — Emerging Practices, Risk Factors, and Red Flags', 27 October 2017, 1, https://medium.com/@wulfkaal/initial-coin-offerings-emergingpractices-risk-factors-and-red-flags-26c41e61a332.

${ }^{9}$ Satis Group, 'Cryptoasset Market Coverage Initiation: Network Creation', 2018, 25.

10 Cura Network, 'Cura Network- We Are Pulling the Plugs On Our ICO Campaign', 5 May 2019, https://medium.com/cura-network/cura-network-we-are-pulling-the-plugs-on-our-ico-campaign9d2dfdbeb02e.

11 Zahrotunnimah, 'Kebebasan Beragama Bagi Kaum Muslimin Di Negeri Jerman', 'Adalah: Buletin Hukum \& Keadilan 3, no. 1 (2019): 20.
} 
as a crypto money project has also gained a place to be the object of study by academics, including Muslim academics. It's just that, as an object of study, the topic of crypto money is often focused on bitcoin (BTC). Even though there are many other crypto coins that are technically different from bitcoin (BTC). In this case alone, there are still differences of opinion among academics about the existence of bitcoin (BTC) as crypto money.

Therefore, it can be concluded that this research is an urgency for several reasons. First, the status given for one type of crypto asset cannot be used to generalize other types of crypto assets, because each type of crypto asset has different characteristics and can have different technical implementations. Second, research relating to crypto assets or crypto money often focuses on bitcoin (BTC) alone, even though there are more than 3000 crypto assets registered on coinmarketcap.com, each of which can have different technical characteristics and implementations with bitcoin (BTC) . Third, the existence of crypto assets and crypto money is sometimes a reason to redefine, what and how the position of money in people's lives. Fourth, the Initial Coin Offering (ICO) as a means of raising funds for crypto asset development projects is often associated with acts of abuse or scams. Therefore, researchers are motivated to study Tixl (TXL) as crypto money, including the Initial Coin Offering (ICO) as a method used

\section{Benefit (al-Mașlaha) as the Basis of Economics and Business}

Progressiveness in business activities and other economic activities, is a real thing that cannot be avoided and arises as a result of the continued development of human needs. This reality is recognized by the sharia, as a fiqh rule which shows that, in the view of Islam a business activity is very flexible, free, but remains in the corridor of sharia, with values that apply universally.

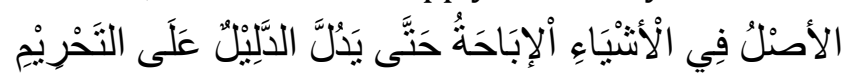

The purpose of the rule is that basically, everything that is permissible may be done until there is an argument forbidding it. ${ }^{12}$ However, the nature of this principle is still so absolute that it must still be given a qayid, until there is an argument that shows its prohibition. With the existence of this qayid, the

\footnotetext{
${ }_{12}$ Adiwarman A. Karim dan Oni Sahroni, Riba, Gharar Dan Kaidah-Kaidah Ekonomi Syariah Analisis Fikih Dan Ekonomi (Jakarta: RajaGrafindo Persada, 2015), vi.
} 
Imam Subarkah

understanding of the above rule is that in places where no prohibition is given, then the law of mubah is determined.13

The proposals of Islamic law agreed by the number of ulama are four, namely Qur'an, Hadith, ijmā', and qiyās. Jumhur scholars also have consensus that the order of use and use in istinbāt is Qur'an, sunnah, ijmä $\bar{a}^{\prime}$, then qiyās. Then, a problem arises, what if the cases that occur in the midst of the community cannot also be resolved through qiyās. Then comes the argument for the adoption of other laws, apart from those previously mentioned, one of which is istișlāh or also known as mașlaha. ${ }^{14}$

Mașlaha mursala consists of two words, namely mașlaha and mursalah. The word mașlaha according to language means "benefit", and the word mursalah means "loose". Abdul Wahhab Khallaf defines mașlaha as something that is considered maslahat but there is no legal certainty to realize it and there are no specific propositions either that support or reject it. 15

Wahbah az-Zuhaili argues that scholars who accept masahlah as hujjah are Malikiyah and Hanabilah scholars. The Hanafiyah group accepted the masses through the istihsan channel. Whereas scholars who reject mașlaha mursalah according to Wahbah are Zahiriyah, Shi'a and the majority of Shafi'iyah and Ibn al-Najib from Malikiyah. Meanwhile, Zakiy ad-Din Sya'ban explained that all the priests of the four sects and the majority of their ashabs accepted the masses as hujjah, so it was not only Imam Malik and his ashab. Zakiy ad-Din argued that even though the priests did not clearly mention the masses as an argument in their essays, they found that many of their ijtihad or fatwas were found in their fiqh books based on their fiqh books. mașlaha. Whereas the ulama who rejected

13 Taufiqul Hulam, 'Jaminan Dalam Transaksi Akad Mudharabah Pada Perbankan Syariah', Mimbar Hukum 22, no. 3 (2010): 520.

14 Maskur Rosyid, 'Merealisasikan Kemaslahatan; Membaca Ulang Metodologi Fatwa MUI', in Peran MUI Dalam Berbangsa Dan Bernegara, ed. M. Asrorun Ni'am Sholeh (Jakarta: Komisi Fatwa Majelis Ulama Indonesia, 2018), 53-55; Maskur Rosyid, Implementasi Konsep Maslahat Al-Tüfi Dalam Fatwa MUI (2005-2010), 1st ed. (Magelang: Ngudi Ilmu, 2013), 46-49; Ahmad Munif Suratmaputra, Filsafat Hukum Islam Al-Ghazali: Maslahah Mursalah \& Relevansinya Dengan Pembaharuan Hukum Islam (Jakarta: Pustaka Firdaus, 2013), 64, 72, 74.

${ }^{15}$ Satria Effendi, Ushul Fiqh, ed. M. Nurul Irfan Aminuddin Ya'kub (Jakarta: Kencana Prenada Media Group, 2008), 148-49. 
the masses were the Zahiriyah group, some Shafi'iyah such as al-Amidi and some Malikiyah such as Ibn al-Najib.16

In this research, mașlaha will be used as grand theory. The theory of mașlaha used is to refer to the views of Abū Hamīd Muhammad ibn Aḥmad alGhazzālī or also known as al-Ghazzālī. Al-Ghazzālì's view on mașlaḥa mursala was used because it was considered relevant to answer the problems that had been raised previously. In addition, al-Ghazzāli's view regarding the problem of the masses is a positive indication in the consideration of establishing Islamic law, in this case al-Ghazzāli is a moderate figure. Not as rigid as those who reject it, not so often as Maliki, and not as brave as al-Ṭüfi. ${ }^{17}$

Grand theory is used as a theory at the macro level, which is also supported by two theories at the mezo or intermediate level, namely the theory of money and the theory of Islamic treaty law. Both of these theories are used as middle theories whose focus of study is on the macro and micro scales. Meanwhile, theories that are at the micro level and are ready to be applied in conceptualization are also called applied theories. In this study using two applied theories, namely the theory of money issuance, and the pillars of agreement.

The theory of money is used as a middle theory in this study, because it adjusts to the substance of the Tixl (TXL) project, which is a crypto currency development project. In various economic flows, money has a big role, for several reasons, which are as follows: ${ }^{18} 1$ ) Money is a barter tool, a benchmark of value, a means of protection of wealth, and a means of payment of debt and cash payments. 2) A strong relationship between money and various other economic activities and the interrelated influences between them. Because a strength that relies on economic power, and a strong economy rests on strong money and vice versa. 3) The emergence of the influence of money in economic life with a very large form, one of which is the monetary crisis. 4) Money is one

\footnotetext{
16 Rosyid, Implementasi Konsep Maslahat Al-Ṭüi Dalam Fatwa MUI (2005-2010), 3-4; Suratmaputra, Filsafat Hukum Islam Al-Ghazali: Maslahah Mursalah \& Relevansinya Dengan Pembaharuan Hukum Islam, 76-77.

17 Regarding al-Ṭüfi's concept of mașlaha, read; Mușțaã Zayd, Al-Maṣlahah Fĩ Al-Tashrī Al-Islāmī Wa Najm Al-Dīn Al-Tüfí (Dār al-Fikr al-'Arābī, 1954); Rosyid, Implementasi Konsep Maslahat Al-Tüfí Dalam Fatwa MUI (2005-2010).

18 Jaribah bin Ahmad Al-Haritsi, Fikih Ekonomi Umar Bin Al-Khathab, ed. Asmuni Solihan Zamakhsyari (Jakarta: Khalifa, 2006), 325-26.
} 
Imam Subarkah

of the factors of economic independence and power. Therefore, money is one of the most important shots in the economic war between countries. When a country's economy wants to be shaken or dropped, all engineering is directed, focusing on the money and playing it with embargoes and others, to shake the value of money, so that the economic system becomes shaky as a whole.

Because money has an urgency as described above, and its indications in various lives, then it is proper if Islamic attention to money is in harmony and in accordance with the urgency. Islam has forbidden anything that has an adverse impact on money. While the problems of ijtihädiya which change due to changes in time and place, then Islam leaves the details to those who are competent to perform jihad in it with what he sees, to be able to realize the benefit of the Muslims, including on the form of currency, the amount of money circulation, and etcetera. ${ }^{19}$

Therefore, the issuance of money is a matter that is protected by the general rules of Islamic sharia. Because the issuance of money and the determination of the amount are things related to the benefit of the people, while playing in the issuance of money will have an impact on the occurrence of great harm to the economy of the people and its benefit. Among the madarat forms are loss of trust in currencies, the occurrence of counterfeiting, swelling of the amount of money and falling value of money (inflation), and the loss of people who have fixed income (income) due to this.

Meanwhile, Islamic legal agreement theory is also used as a middle theory to find out the legal status of the transactions in the Initial Coin Offering (ICO) held by the Tixl Team. According to Syamsul Anwar, the agreement is a meeting of consent and Kabul as a statement of the will of two or more parties to give birth to a legal effect on the object. This definition confirms that:20 1) An agreement is a connection or consent meeting and Kabul which results in legal consequences. Al-Ijjāb is an offer submitted by one of the parties, and Kabul is an answer to the agreement given by the agreement partner in response to the offer of the first party. An agreement cannot occur if the statement of the will of each party is not related to each other because the agreement is the interconnection of the will of the two parties as reflected in the consent and

${ }^{19}$ Al-Haritsi, 326.

${ }^{20}$ Syamsul Anwar, Hukum Perjanjian Syariah (Jakarta: RajaGrafindo Persada, 2010), 68-69. 
consent. 2) The agreement is a legal action of two parties, because the agreement is a meeting of consent that represents the will of one party and Kabul which states the will of the other party. 3) The purpose of the agreement is to have a legal effect. The purpose of the agreement is the intended joint goal which is intended to be realized by the parties through the making of the contract.

There are two legal consequences of an agreement, namely the main legal effect and additional legal consequences. The principal legal effect is the legal effect which is a common goal that the parties want to realize, using the agreement as a means to realize it. Meanwhile, the additional legal agreement is also called the rights of the agreement, the rights and obligations arising from the agreement such as the seller must surrender the goods in the sale and purchase transaction, and the buyer must provide other objects as a medium of exchange for the goods submitted by the seller. ${ }^{21}$

It should be emphasized that the purpose of the agreement is to realize the main legal consequences of the agreement. For example, the purpose of a sale and purchase agreement is to transfer ownership of the goods in return, the purpose of the lease agreement is to transfer ownership of the benefits of the goods leased to the lessee in return, and the purpose of the grant is to transfer ownership without compensation. ${ }^{22}$

\section{Factors Underlying Tixl Ggmbh Using Initial Coin Offering (ICO) as a Way to Collect Funds}

Initial Coin Offering (ICO) is a fundraising process carried out by the Development Team to finance their blockchain projects by selling crypto assets that are also part of the project. Initial Coin Offering (ICO) is used as a means of collecting funds, because it is motivated by several things, are those:

\footnotetext{
${ }^{21}$ Anwar, 218.

22 The purpose of an agreement is marked by several characteristics, namely objective, in the sense of being in the agreement itself, does not change from one agreement to another agreement of the same type, and is therefore independent of the wishes of the parties because the purpose of this agreement, especially in the case of the named agreement determined by Lawmakers. Second, determining the type of legal action, in the sense that the purpose of the agreement distinguishes one type of agreement from another type of agreement. Third, the purpose of the agreement is the legal function of legal action in the sense that the purpose of the agreement forms the legal objective, both from an economic and social point of view, which should not be realized by the legal action concerned. Anwar, 218-20.
} 
Imam Subarkah

\section{There is a change in orientation in the business model}

The business ecosystem is important for business models that are platform oriented. Sellers, distributors, buyers, and other economic actors participate and join in a platform to form effective and efficient business interaction patterns. Often, a monetary unit is also used and functions in the business ecosystem. This monetary unit, has an important role in the platform. For example, OVO and GoPay balances, which are monetary units that function on each of these platforms. With this monetary unit, transactions that occur also become more effective and efficient. In fact, both of them, are possible to be used outside the platform, because basically both of them have been recognized by the government and the community in Indonesia.

An example relating to the crypto asset industry is the Basic Attention Token (BAT). Basic Attention Tokens are quite popular in the crypto asset industry because of the system they have. The Development Team from the Basic Attention Token (BAT) seeks to improve the efficiency of digital advertising by using BAT as a unit of value that can be exchanged and valid among publishers or content creators, advertisers and Brave web browser users. Brave web browser users will be given incentives in the form of a number of BAT for their attention to existing advertisements. Likewise, publishers or content creators who are part of this service, can receive a number of incentives from advertising revenue. Users can also make donations to publishers or content creators that they like using BAT.

\section{There is tokenization}

Tokenisasi and blockchain are two interrelated things. Blockchain has enabled tokenization of traditional assets, thus allowing these assets to be traded by the public. Blockchain becomes so important because blockchain is able to prevent double spending and overcome Byzantine General's Problem, two problems that are feared to disrupt transactions using electronic money.

\section{Characteristics of business activities}

Start-up can be interpreted as a startup. The term is then very popular and is always associated with new businesses that produce digital products, such as web services, applications, or games. In the crypto asset industry, the 
Development Team offers innovative ideas based on the blockchain and produces various digital products, like start-up companies. So often the term blockchain start-up is used as a nickname for a company or Development Team whose business activities are based on the blockchain. Ideally, as a start-up business, start-up is developed through several stages, namely ideation, product development, getting user and marketing, rapid growth, maturity, steady growth or decay.

After the idea for a start-up is sparked, a team can be formed to realize the idea. The process of realizing this idea was carried out during the development phase. In this phase, the start-up needs funding to realize the idea. With regard to this initial funding, start-ups will find it difficult to submit funding requests to bank financial institutions because this startup does not yet have cash flow, and has not even entered the market. In contrast to venture capital companies, which outline one of the aims and objectives of its establishment is to help the establishment of new companies, where the level of risk of loss is very large.

Meanwhile, by using the Initial Coin Offering (ICO), start-ups have a greater opportunity to build a community along with the publication of an idea that will be realized. Through whitepaper, blockchain start-up can inform all aspects related to the idea and project. This is like forming a new market or a new business ecosystem, even before the product development phase is complete.

The Tixl Team itself said that the Tixl (TXL) development process needed funding. The Tixl development (TXL) phase and the Tixl ledger implementation will be carried out step by step. However, there are a number of related aspects that need to be driven, such as social media, accounting, legal and tax services, and security audits. In addition, costs are also required to register on the Crypto Asset Exchange. Some Crypto Asset Exchanges may receive Tixl (TXL) without a financial contribution, or in return for an amount in Tixl (TXL) it self. To be accepted as crypto money by the market, Tixl (TXL) needs to be traded on the main Crypto Asset Exchange which often requires a 'six digit' payment for registration.

In addition, hosting of Tixl nodes (TXL) must be decentralized over time. However, in the early days, the Tixl Team had to provide nodes and had to bear the appropriate monthly costs for the computing infrastructure. Tixl (TXL) as a crypto money project will only be successful if there are many people who use Tixl (TXL) for payment. For this reason, a number of marketing campaigns will 
Imam Subarkah

be held, some marketing campaigns such as working with influencers or business-to-business partnerships, will be able to use Tixl (TXL), but others will require payment in fiat money. Lee and Low's opinion about the Initial Coin Offering (ICO) as a means of raising funds without giving up equity or control over the company, was not rejected by the Tixl Team (TXL) and was instead confirmed in the Tixl Token (TXLT) purchase agreement.

\section{Tixl (TXL) As A Crypto Money Project in The Perspective of Mașlaha Mursala}

In an economic system, a medium of exchange is included in the needs that are at the level of darūrī, because with the existence of a medium of exchange human beings can avoid ribawi transactions. This need is then realized at the level of hajjī, namely through the use of fiat money as a medium of exchange.

Tixl (TXL) as crypto money which is currently still under development projects, is a requirement that is included in the tahsiniyat category. Because, Tixl (TXL) only has the potential to be used as alternative money and is included in the category of private money. The use of Tixl (TXL) as money will certainly not disrupt the existing economic system, because Tixl (TXL) is not a legal tender as fiat money, but only as alternative money subject to agreements and private law.

The benefit arising from the use of Tixl (TXL) as money is juz'ī benefit, because it can only be felt by some people, namely users of Tixl (TXL). The benefit in the form of ease of transaction, fast, free and private transactions. Conversely, the use of Tixl (TXL) as money can cause harm, including the emergence of competition in purchasing power and stability between Tixl (TXL) with public money or fiat money. Tixl (TXL) is also feared to be used for transactions relating to criminal acts, money laundering and terrorism financing.

The harm arising from the use of Tixl (TXL) has the potential to be felt as a whole. The harm caused by Tixl (TXL) as a crypto money project, is caused by two things, namely the absence of restrictions on the function of Tixl (TXL) and the value of Tixl (TXL) that are not related to the value of fiat money issued by a country. Therefore, Tixl (TXL) as a crypto money project, is feared that it will evoke discourse on currency denationalization, which can cause loss of state control and public trust in public money or fiat money itself. Such potential is 
possible if the community of Tixl (TXL) has developed rapidly and Tixl (TXL) is widely accepted, just like public money.

The harm caused by Tixl (TXL) as a crypto money project is at the level of darūrī, because it is feared that it will disrupt the stability of public or fiat money issued by a certain country. It is also feared that this could lead to instability in the economic and political fields, meaning that a country's stability can also be disrupted, because public money or fiat money is the identity and symbol of a country's economic sovereignty.

Therefore, Tixl (TXL) as a crypto money project that has no function and value constraints that are not related to public money can cause misunderstanding that can disrupt the five main elements of the maqāsid alshari'a, namely religion, soul, reason, wealth and descent, the five elements this is clearly closely related to the stability of a country. For this reason, it is important to reject the existence of Tixl (TXL) as a crypto money project because of the potential harm it can cause. As a rule of Islamic law which confirms that

"Rejecting prejudice takes precedence over benefits."23

$$
\text { درء المفا سد مقدم على جلب المصا لح }
$$

\section{Transactions in Initial Coin Offering (ICO) Tixl (TXL) in the} Perspective of Islamic Agreement Law

The inclusion of Tixl gGmbH in the commercial list in the German territory, shows that the authorization requirements as an organizer have been fulfilled. Tixl gmbH in the Initial Coin Offering (ICO) he held, played the role of Seller. Whereas the Buyer is an individual or legal entity that purchases Tixl (TXL) in the Initial Coin Offering (ICO) phase.

Tixl GGmbH as the organizer seems to have a qualified background to hold an Initial Coin Offering (ICO) and realize the projects offered. This means Tixl gGmbH can be deemed appropriate and has the skills to carry out the transaction.

Meanwhile, the Buyer must meet certain criteria set by the Seller, including the issue of ability to make transactions and extensive knowledge related to the

23 A. Djazuli, Kaidah-Kaidah Fikih: Kaidah-Kaidah Hukum Islam Dalam Menyelesaikan MasalahMasalah Yang Praktis (Jakarta: Kencana, 2001), 18. 
Imam Subarkah

Initial Coin Offering (ICO) and / or Initial Decentralized Exchange Offering and / or Initial Exchange Offering (IEO), especially in the Tixl (TXL) project. The ability to make this agreement is proven by the identity and various other documents owned by the Buyer. Meanwhile, extensive knowledge related to Initial Coin Offering (ICO) and / or Initial Decentralized Exchange Offering and / or Initial Exchange Offering (IEO), especially on the Tixl (TXL) project, is proven by activating the checkbox before the purchase transaction is made.

In this phase, Tixl (TXL) which is still in the development phase will be represented by Tixl Token (TXLT). Tixl Tokens (TXLT) are tokens based on the Binance Chain with the asset code MTXLT-286. Tixl Tokens (TXLT) are objects in this agreement and are confirmed by the Seller in the General Terms and Conditions of the Tixl Token Seller (TXLT).

Keep in mind that Tixl Tokens (TXLT) are only representations of Tixl (TXL), so the Seller in good faith must complete the Tixl (TXL) project. The seller also said that to realize Tixl (TXL) as crypto money, the token exchange phase of Tixl Tokens (TXLT) based on Binance Chain with Tixl (TXL) based on the Tixl blockchain (TXL) will be held after the development phase of Tixl has been completed.

In the Initial Coin Offering (ICO) phase, the Tixl Team as the Seller has submitted an offer or permission to the Buyer openly, through documents containing the General Terms and Conditions of the Sales of Tixl Tokens (TXLT) published on the Seller website, together with other documents, like a whitepaper. To respond to this offer or consent, the Buyer must first meet the qualifications set by the Seller. After that, the Buyer can submit the gratuity or acceptance of the consent online, by following the procedures set by the Seller.

The purpose of the agreement in the sale of Tixl Tokens (TXLT) is not only to transfer ownership of Tixl Tokens from the Seller to the Buyer. The funds used from the sale of the Token will be used to finance the development of the Tixl (TXL) project. This is a cause which has also been confirmed in several documents that have been published by the Seller, one of which is the whitepaper.

In view of treaty law, a treaty must be valid, that is, it does not conflict with the provisions of Islamic law. According to the Hanafi school of thought is null and void the sale and purchase agreement of dates or wine to be made khamr, 
because the purpose, namely the cause is contrary to the provisions of Islamic law. In this connection, and as explained in the previous section, it can be concluded that the Tixl (TXL) project cannot fulfill the requirements of this pillar.

In its legal technique, Islamic law follows a synthetic view which sees legal action as a whole and makes the source of the engagement the starting point for the establishment of its legal provisions. If a legal action has fulfilled the requirements specified for its validity, then the legal action becomes a valid legal action, which sharply results in legal consequences. If one of the conditions is not fulfilled, the legal action is null and void and can have no legal consequences. Agreement as a legal action cannot be separated from this rule. Therefore, to be able to give birth to legal consequences, the contract must meet the conditions established by law against it.

Based on what has been explained in the previous section, it is known that the Tixl Token (TXLT) sale transaction in the Initial Coin Offering (ICO) conducted by Tixl gmbH, is a transaction that is against sharia. Because, Tixl (TXL) as the object of the agreement can cause kemudharatan, which has the potential to cause competitiveness between Tixl (TXL) with existing public money, which is further feared will arouse the discourse of currency denationalization, potentially causing loss of state control and public trust in public money itself.

Such potential is possible if the community of Tixl (TXL) develops rapidly and is as widely accepted as public money. But if on the contrary, Tixl (TXL) will only become private money used by the community, and potentially bring benefit to the human side only. The potential mudharat of Tixl (TXL) as an object of agreement is in its system that promotes anonymity and privacy. This will certainly be worrying if Tixl (TXL) is misused for criminal acts.

\section{Conclusion}

The results of this study indicate that there are three things that underlie the use of the Initial Coin Offering (ICO) as a way of raising funds, namely a change in orientation in the business model, tokenization, and characteristics of business activities. As a crypto money project, Tixl (TXL) cannot provide a whole or kully benefit, even the potential harm that can be generated from the Tixl (TXL) project is greater than the benefit. So, in cases like this, eliminating harm must be preferred. Therefore, the token sale transaction in the Initial Coin 
Imam Subarkah

Offering (ICO) held by Tixl (TXL) is a vanity transaction because it is contrary to maqāṣid al-sharīa. [a]

\section{BIBLIOGRAPHY}

Anwar, Syamsul. Hukum Perjanjian Syariah. Jakarta: RajaGrafindo Persada, 2010.

Cura Network 'Cura Network- We Are Pulling the Plugs on Our ICO Campaign', 5 May 2019. https://medium.com/cura-network/cura-network-we-arepulling-the-plugs-on-our-ico-campaign-9d2dfdbeb02e.

Dannen, Chris. Introducing Ethereum and Solidity. New York: Apress, 2017.

Darmawan, Dimaz Ankaa Wijaya; Oscar. Blockchain Dari Bitcoin Untuk Dunia. Jasakom, 2017.

Dell'Erba, Wulf A. Kaal; Marco. 'Initial Coin Offerings - Emerging Practices, Risk Factors, and Red Flags', 27 October 2017. https://medium.com/ @wulfkaal/initial-coin-offerings-emerging-practices-risk-factors-andred-flags-26c41e61a332.

Djazuli, A. Kaidah-Kaidah Fikih: Kaidah-Kaidah Hukum Islam dalam Menyelesaikan Masalah-Masalah yang Praktis. Jakarta: Kencana, 2001.

Effendi, Satria. Ushul Fiqh. Edited by M. Nurul Irfan Aminuddin Ya'kub. Jakarta: Kencana Prenada Media Group, 2008.

Eichinger, Christian, Christian@tixl Me, Sebastian Gronewold, Sebastian@tixl Me, Bernd Strehl, and Bernd@tixl Me. 'Tixl Whitepaper', 2019. https://medium.com/tixlcurrency/tixl-token-sale-phase-3-officialstart-41a9f0ee504c.

Al-Haritsi, Jaribah bin Ahmad. Fikih Ekonomi Umar Bin Al-Khathab. Edited by Asmuni Solihan Zamakhsyari. Jakarta: Khalifa, 2006.

Hulam, Taufiqul. 'Jaminan dalam Transaksi Akad Mudharabah pada Perbankan Syariah'. Mimbar Hukum 22, no. 3 (2010).

Kelly, Brian. The Bitcoin Big Bang. Jakarta: PT Elex Media Komputindo, 2018.

Nakamoto, Satoshi. 'Bitcoin: A Peer-to-Peer Electronic Cash System', n.d. www.bitcoin.org.

Rosyid, Maskur. Implementasi Konsep Maslahat al-Ṭüfi dalam Fatwa MUI (20052010). 1st ed. Magelang: Ngudi Ilmu, 2013. 
- - ' 'Merealisasikan Kemaslahatan; Membaca Ulang Metodologi Fatwa MUI'. In Peran MUI dalam Berbangsa dan Bernegara, edited by M. Asrorun Ni'am Sholeh, 41-57. Jakarta: Komisi Fatwa Majelis Ulama Indonesia, 2018.

Sahroni, Adiwarman A. Karim dan Oni. Riba, Gharar dan Kaidah-Kaidah Ekonomi Syariah Analisis Fikih dan Ekonomi. Jakarta: RajaGrafindo Persada, 2015.

Satis Group. 'Cryptoasset Market Coverage Initiation: Network Creation', 2018.

Suratmaputra, Ahmad Munif. Filsafat Hukum Islam al-Ghazali: Maslahah Mursalah \& Relevansinya dengan Pembaharuan Hukum Islam. Jakarta: Pustaka Firdaus, 2013.

Zahrotunnimah. 'Kebebasan Beragama Bagi Kaum Muslimin di Negeri Jerman'. 'Adalah: Buletin Hukum \& Keadilan 3, no. 1 (2019).

Zayd, Mușțafā. Al-Mașlahah fí al-Tashrī’ al-Islāmī wa Najm al-Dīn al-Ṭūi. Dār alFikr al-'Arābī, 1954. 
